Spring 2007

\title{
Teaching Incest in Medieval Literature, Culture and Law
}

George D. Greenia

William and Mary, gxgree@wm.edu

Follow this and additional works at: https://scholarworks.wm.edu/aspubs

Part of the Bioethics and Medical Ethics Commons, Comparative Literature Commons, Counseling Commons, Criminology and Criminal Justice Commons, European Languages and Societies Commons, Medical Education Commons, Medieval History Commons, Medieval Studies Commons, Other Spanish and Portuguese Language and Literature Commons, and the Women's Studies Commons

\section{Recommended Citation}

“Teaching Incest in Medieval Literature, Culture and Law." La corónica 35.2 (Spring 2007): 15-37.

This Article is brought to you for free and open access by the Arts and Sciences at W\&M ScholarWorks. It has been accepted for inclusion in Arts \& Sciences Articles by an authorized administrator of W\&M ScholarWorks. For more information, please contact scholarworks@wm.edu. 


\section{YEARS}

\section{PROJECT MUSE*}

\section{Teaching Incest in Medieval Literature, Culture and Law}

George D. Greenia

La corónica: A Journal of Medieval Hispanic Languages, Literatures, and Cultures, Volume 35, Number 2, Spring 2007, pp. 15-37 (Article)

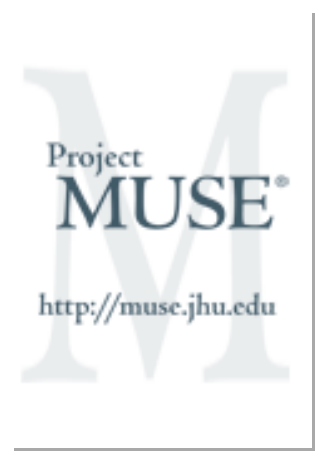

Published by La corónica: A Journal of Medieval Hispanic Languages, Literatures, and Cultures

DOI: https://doi.org/10.1353/cor.2007.0015

$\Rightarrow$ For additional information about this article

https://muse.jhu.edu/article/429786/summary 


\section{TEACHING INCEST IN MEDIEVAL LITERATURE, CULTURE AND LAW}

\section{George D. Greenia \\ College of William \& Mary}

As Editor of this journal I do not normally offer contributions to these pages other than my "Del director" column and an occasional book review as assigned and edited by another member of the senior staff. But this Cluster on The Riddle of Incest has a back story that may be of interest to those who teach courses that embrace social issues and the history of sexuality.

Starting over a decade ago at the College of William \& Mary, the Program in Medieval \& Renaissance Studies, for which I served as Director during the $90 \mathrm{~s}$, began to offer periodic multi-section onecredit courses on topics that invited shared expertise and multiple disciplinary perspectives. Each section met for eight weeks with some common readings and others selected from the research area of the instructor. We inaugurated our series of one-credit topics courses in 1992 with Patrick Geary's Furta Sacra: Thefts of Relics in the Central Middle Ages, for a course titled The Theft of Relics -jokingly billed as "Body Snatching in the Middle Ages"- and designed sections on relics and pilgrimage (taught by our medieval historian), Byzantine icons and relics (taught by a colleague in Religious Studies), the evolution of the reliquary as an art historical object (with an art historian as instructor), and my own section on relics and medieval spirituality.

As the core of this undergraduate experience, we always read a major recent book on the subject and invited the author to campus for the standard public lecture and luncheon discussion with faculty, but also for a private catered breakfast for the author and the students enrolled, informal sessions which no faculty member could attend. Finished books have a false air of closure to them. Working scholars know the mess that's left in our offices, the side topics we silenced for the sake of finishing the project, the leads we dared not follow quite 
yet, the cherished theses abandoned as we assembled documentation for an argument that changed as we worked. The breakfast interview was the uncensored peek into the workshop when students got to privately ask an author what she found that surprised her, what she left purposely omitted, where her own expertise ran aground, where a later complementary articlc or even second book would balance the picture, what other researchers would have to take up.

Patrick Geary did an excellent job of launching this series and other guest authors who came to campus -John Boswell for a course on The Abandonment of Children, E. Ann Matter on The Song of Songs in the Middle Ages, Edward Peters for Inquisition, James Tabor who helped us teach The Book of Revelation: From Rome to Waco, Alison Weber for Women and Mysticism: Teresa of Ávila- all embraced the format and gave us brilliant lectures and prompted challenging conversations.

In the Spring of 2002 we resolved to prepare another interdisciplinary course on Incest in Medieval Litcrature, Culture and Law. It was not a casual decision: a few years earlier we had talked about mounting a course on suicide in literary and cultural studies and eventually, well, chickened out. The material to read and discuss was certainly rich and intriguing and the interdisciplinary approach provided a calming distance and professionalization to an inherently disturbing topic. But how would undergraduates react? Could we handle their unpredictable emotional responses? What if some tried to harm themselves because we filled their imaginations with terrible possibilities or somehow validated the dark fears that already haunted them?

Teaching incest was not going to be much easier, so we started more programmatically, with a faculty seminar the preceding May. Campus participants included a clinical psychologist, a physician from the student health center and an anthropologist, as well as faculty from literature and history. ${ }^{1}$ It seemed crucial that the Counseling Center staff were kept in the loop in case they started to notice a spike in campus conversations about incest reflected in their clients' voiced concerns. Campus clinical psychologists were invited to brief the teaching faculty and reacquaint themselves on issues that might arise and they helped us decide against the use of a "safety contract" sometimes employed when conducting seminars on suicide, basically a

${ }^{I}$ I would like to thank the scnsitive and insightful contributions of faculty and staff at the College of William and Mary, including Michael Blum, John Conlee, June Henderson, Virginia Kerns, Monica Potkay and Carina Sudarsky-Gleiser: My William \& Mary colleague Elizabeth Barnes, who edited Incest and the Literary Imagination (Gainesville: UP of Florida, 2002), also contributed at a later stage. 
promissary note that no one in the group will attempt to harm him- or herself during the run of the course.

The instructional faculty felt that in this instance requiring students to sign a safety agreement would only enhance possible tensions about studying incest. We did open the course with an admission that this could be a troubling subject for some in the class and that we would commit ourselves to discussing it respectfully, not knowing what each individual might be bringing to the table or deliberately keeping quiet. And we affirmed that it was understandable for everyone studying a subject like this to start to review their own life experiences and wonder "Did that count?" Only one student reported a spin-off problem we had not anticipated: guilt by association. A young man in my own section mentioned to his roommate that he was taking a course on incest and the other youth pulled back in embarrassment saying, "Dude, I didn't know that was an issue with you".

Our entire program design was shared in advance with our special guest author, Elizabeth Archibald (Incest and the Medieval Imagination), whose sensitive and informative presentations -to faculty, students enrolled in the formal course on Incest in Medieval Literature, Culture and Law, even to the entire staff of our Counseling Center-were models of professionalism and welcome good humor.

This one instance of a challenge for the classroom is in a small way representative of the fierce mandate of our field. Medieval studies embrace a heady array of topics that challenge and upset, from alternate models for marriage to institutionalized violence. It's precisely the historical distance of the periods we study that offers us the advantage of examining troubling content at arm's length and with detachment, and seeing how our own culture confronted perennial issues in surprisingly different ways. Our stewardship of higher education in its most challenging areas of inquiry is a showcase of the power of the Humanities to scrutinize evil and good as defined in other times and in cultures we claim as our own.

In consultation with Emily Francomano, the Guest Editor of this Critical Cluster on The Riddle of Incest in Medieval Iberia, we would like to offer three Appendices that our readers may find helpful in their own research and teaching.

The first Appendix offers a repertoire of Hispanic tales that deal with the incest theme, many of them discussed in greater detail in the articles in this Critical Cluster. 
The second Appendix is offered for those contemplating teaching about incest -or any sensitive topic that undergraduates might find emotionally challenging. It offers a set of guidelines for class management that may provide an extra measure of responsible planning and openness. These guidelines were developed by college faculty who taught our seminar on Incest in Medieval Literature, Culture and Law and I include in italics reflections specific to the course on medieval incest taught at the College of William \& Mary in 2003.

A concluding Appendix gives a reference bibliography on incest in classical and medieval studies, broader in nature than that contained in any of the individual articles in this Cluster.

\section{APPENDIX 1 MEdieval Iberian NARRATIVes of InCEST}

This short checklist only includes the most prominent tales from the Iberian Middle Ages which contain incest themes, whether merely threatened, narrowly averted, or fully completed. The Iberian tradition seems to reflect the general European tradition amply documented by Elizabeth Archibald that ranks father-daughter incest the most reprehensible, mother-son incest as also sinful but more likely to be explained by feminine sentiment, and brother-sister incest the least troubling of all. The high frequency with which girls who lacked the means to secure an honest marriage drifted into prostitution, and the routineness with which men availed themselves of women trapped in that state of life, meant that the risks of unwitting and involuntary incest was fairly high outside the village context. And even within villages, the ritualized practice of the abandonment of children who were then raised by other families produced not uncommon instances of siblings finding themselves attracted to one another and cscaping incest only through the invocation of the communal memory. The formal proclamation of the banns of marriage in advance of blessing any union allowed the elders who knew of the true if hushed-up relationships of everyone in the community to inform concern parties before things went too far.

Any examination of the literary landscape of a period needs to check itself against the religious ideals of its times and the legal injunctions that tried to channel human conduct. Both of their currents are surveyed by authors in this Cluster: Paul Brian Nelson for the former and Teresa Catarella and Louise Vasvári for the latter. But there is far 
more work to be done on both fronts. Relevant passages from the Siete partidas and other law codes of the period reveal some of the legal reflections of the period but many other sources need to be considered. Working mostly from municipal charters, Heath Dillard points out repeatedly the control that fathers routinely exercised over their daughters' sexual fates, also expressed in Visigothic law and in the Fuero Juzgo as his potestas de coniunctione or nearly absolute right to decide her marriage, and therefore sexual partner. Lacking a father's consent, "the daughter was punished for elopement by disinheritance or worse, and the unapproved husband could be outlawed as an abductor" (41). Such intimate authority could slip into dominance or blackmail, extorting for himself the favors a girl could not grant anyone else.

Traditional folktales, mostly gathered after the medieval period during the post-Romantic era and even more insistently during the rise of systematic ethnographic field work carried out at the end of the nineteenth century and throughout the twentieth, also document many stories of incest. There is a modern prosified version of the "Delgadina" story adopted from a ballad source. ${ }^{2}$ And from Puerto Rico we find the story of "Los tres trajes": father-daughter incest temporarily thwarted by obstacles invented by the girl who then flees from her perverse suitor. This tale interestingly finishes by flirting with motherson incest when a possessive parent tries to take credit when the lovesick youth is cured by his beloved's gift of food. ${ }^{3}$

${ }^{2}$ Number 46 in Cuentos populares españoles, edición de José María Guelbenzu (Madrid: Siruela, 2006), 166-67; but in this case Guelbenzu notes that "el cuento «Delgadina» procede de un romance, recogido por Luis Cortés Vázquez en sus Leyendas, cuentos y romances de Sanabria [3a ed., Salamanca: Gráficas Cervantes, 1992], que me he permitido convertir en cuento" (378).

${ }^{3}$ Number 11 in Cuentos folklóricos latinoamericanos. Fábulas de las tradiciones hispanas e indígenas, Ed. John Bierhorst (NY: Vintage Español, 2003), 58-62. The editor takes his anthologized version from J. Alden Mason, "Porto-Rican Folklore: Folk-Tales". Editado por Aurelio M. Espinosa. Journal of American Folklore 38 (1925): 572-74. Another tale of averted incest in the same anthology is Number 77, "El monstro de siete cabezas", 23844, taken from Howard T. Wheeler, Tales from Jalisco, Mexico (Philadelphia: American Folklore Society, 1943), number 57.

Another folktale, the dark "El hombre del saco", recounts the abduction of a frail girl by a sinister, bogeyman figure who confines her in a sack and makes her perform at his demand. This story turns predatory sexual behavior into an offence punished by both nature and society. The offense is displaced outside the family in this version, a family strangely comprised of only a mother and older sisters with no mention of a father other than lumped casually as "los padres", so the sole reference to masculine agency belongs to the villain who could be abusive husband or other relative. Cf. Number 2 in Cuentos populares españoles, 2729. Guelbenzu copies this story from José Antonio Sánchez Pérez's Cien cuentos populares españoles ( $2^{\mathrm{a}}$ ed., Palma de Mallorca: José J. de Olañeta, 1995) first published in 1942. 
Brother-sister incest appears in a thinly veiled form in the Guatemalan tale "Juan María y Juana María". The lovers are the children of nameless amigos who "se querían mucho" and whose equally nameless wives oppose the marriage of their children. The nearly identical names of the besotted youths insinuate that they were more than primos espirituales (the parents seem to have been at least compadres) but as siblings and even facing mirrors. They pledge their mutual faithfulness in a letter written in blood and leave home only to be imprisoned for unspecified offenses, perhaps the incestuous attraction itself. The lad attracts the attention of a passing noble daughter who frees him from his incarceration and moral impasse and the strangers promise to wed. The boy's "sister", however, is unhinged by this threat and emerges as a phantasm draped in shroud and chains to slay him on his wedding night before being carried off herself by demons.

Finally, the two volumes by Harriet Goldberg that offer motifindexes of the traditional Spanish folktale and ballad on the AarneThompson model are excellent resources, hopefully to be complemented by a third volume still forthcoming in the same MARTS series at the University of Arizona.

\section{Doña Urraca, daughter of Fernando III and sister of royal princes Alfonso, Sancho and García}

In the mostly lost epics dealing with the Cerco de Zamora and in the subsequent ballad tradition there were frequently accusations of Urraca threatening her family nembers that she would have to resort to prostitution because they had "disinherited" her. Among thirteenthcentury historians, both Christian and Moor, there are also references to a clandestine - or even open-incestuous relation between Lrraca and her brother Alfonso VI who had exiled the Cid, Rodrigo Díaz de Vivar.

Johannes Aegidius Zamorensis (Fray Juan Gil de Zamora, OFM). De preconiis hispanie. Estudio preliminar y edición crítica de Manuel de Castro y Castro, OF M. Madrid: L de Madrid, 1955. pp. 189-90: "Ut subveniatur sibi, et precipuc per filios, consigueneos et propinquos, iure propinquitatis prohibita fuit fornicatio cum soluta..."

\footnotetext{
${ }^{+}$Number 29 in Cuentos folklónicos latinoamericanos. Fábulas de las tradiciones hispanase indígenas, Ed. John Bierhorst (NY: Vintage Español, 2003), 129-23. The editor takes his anthologizcd version from Adrián Recinos, "Cucntos populares de Gautemala". Journal of American Folklore 31 (1918): 472-73.
} 
pp. 249-72: Urraca, filia Fernandi I

p. 344: "Exhibeatis vos Iheu [IV Regnum 9:30] incestuosis..." Abu Bakr ibn al-Sayrafi, Moorish historian.

See articles by Teresa Catarella and Erik Eckman in this issue.

STEPMOTHER TRIES TO SEDUCE HER ADOPTED SON (PARALlELS MODEL of the wife of Potiphar and Joseph in Genesis 39: 1-20)

Libro de los engaños de las mujeres [Sendebar]. Stepmother and son; resembles wife of Potiphar story

Libro de los engaños de las mujeres [Sendebar]. Edición de María Jesús Lacarra. Madrid: Cátedra, 1989.

Libro de los exemplos por a.b.c. by Clemente Sánchez de Vercial (¿14291438?), compilation of 460 exenplos with some 546 exemplary tales. Ejemplo 172, Cuento de la madre que no pudo corromper a su hijo y lo denunció como violador a la justicia, pero éste pidió ayuda de San Andrés. Ed. crítica por John Esten Keller. Vocabulario etimológico por Louis Jennings Zahn. Madrid: CSIC, 1961. Reimpresión Madrid: Ars Libris, 2000.

\section{See article by Paul Brian Nelson in this issue.}

\section{La Virtuosa dama qUe PECA CON SU HiJO}

Cantigas de santa Maria by Alfonso X el Sabio (hacia 1270-80). Cantiga 17 , text in Galician-Portuguese, semi-independent miniatures in the Códice rico copy.

Libro de los exemplos por a.b.c. de Clemente Sánchez de Vercial (¿14291438?), compilación de 460 exenplos (apartados) con 546 historias ejemplares. Ejemplo 274, "La señora de Roma”, texto en castellano. Ed. crítica por John Esten Keller. Vocabulario etimológico por Louis Jennings Zahn. Madrid: CSIC, 1961. Reimpresión Madrid: Ars Libris, 2000.

Recull de Eximplis, $\$ 276$, Catalan, The incestuous union of mother and son with her being denounced by a devil in the form of a cleric. Other Latin versions of same tale:

Dialogus miraculorum by Caesarius of Heisterbach (German), dist. 2, chapter $11^{5}$

Speculum historiale by Vicente de Beauvais (French), 18b, 8, chapter 93

${ }^{5}$ Caesarius of Heisterbach (ca. 1180-ca. 1240). The Dialogue on Miracles [1220-1235]. Trans. H. von E. Scott and C.C. Swinton Bland, with an introduction by G.G. Coulton. London, G. Routledge \& Sons, Ltd., 1929. 
Scala coeli, num. 257

Gesta romanorum, $\$ 13^{6}$

\section{See article by Paul Brian Nelson in this issue.}

\section{An Incestuous Union WHICH ENGENDERS A MONSTER}

Amadis de Gaula, a union between a father (who is a giant) and his daughter which produces Endriago: Libro II, cap. 73.

\section{King Antioco ravishes his daughter and prevents anyone} FROM MARRYING HER BY IMPOSING AN IMPOSSIBLE TEST; Apolonius, king of Tyre, is drawn to daughter he has NEVER KNOWN AS AN ADULT

Libro de Apolonio, anonymous Castilian poem in cuaderna vía from mid thirteenth century, with two more Castilian versions of the story of Apolonius of Tyre edited by Mlan Deycrmond.

See pertinent sections of Elizabeth Archibald, Incest and the Medieval Imagination, and Isabel Lozano-Renieblas, Novelas de aventuras medievales: género y traducción en la Ldad Media hispánica.

Abandoned mother takes consolation in her own beloved son El conde Lucanor by don Juan Manuel, Ejemplo 36, The merchant who abandons his pregnant wife and returns years later to find her in bed with a youth (their son) whom she fondly call "husband" out of pining for her lost husband.

\section{THE MOTHER WHO SLEEPS WITH HER LOST SONS AFTER THEIR} EMOTIONAL REUNION

Libro del caballero Zifar, anonvmous (ca. 1320), Castilian, Capítulo 94 (in the edition of Cristina González, 210; in the edition of Jesús Cañas Murillo, 181-82).

\section{French tale of a GaSe of incest between father and daUghter} El Victorial, Libro II, capítulo 62, 1431-1453, Castilian

The Duke of Guiana (or "Guyena", formerly Guyenne, now in the Départment of Gironde, capital Bordeaux) is unhinged by the

\footnotetext{
${ }^{6}$ Gesta Romanorum; or: Entertaining moral slories; invented by the monks as a fireside recreation. and commonly applied in their discourses from the pulpit: uhence the most celebraled of our oun poets and olhers, from the earliest times, have extracted their plots. Translated from the Lat in, with pretiminary observations and copious noles, by Charles Szan. [1894] Rev. and corr. by Wynnard Hooper. New York, AMS Press, 1970.
} 
death of his wife and takes comfort in his daughter who seems a perfect replica of the deceased wife. The Duke resolves to forego a normal remarriage in favor of publically take the girl as his bride, and forcibly kissing her hands in sign of betrothal. Shamed by the sinful advances of her father, the daughter has a servant cut off the hands that were kissed and in retribution the father casts her onto the seas in an empty boat. The Virgin restores her hands and aids her in achieving marriage to a prince of England.

Díaz de Games, Gutierre, ca. 1379-ca. 1450. El victorial; crónica de don Pero Niño, conde de Buelna, por su alférez Gutierre Diez de Games. Edición y estudio por Juan de Mata Carriazo. Madrid: Espasa-Calpe, 1940. pp. 177-82. [BN-Madrid, MS 17648] -. El Victorial. Crónica de Pero Niño, conde de Buelna, por su alférez Gutierre Diez de Games. Ed. Rafael Beltrán Llavador. Salamanca: U de Salamanca, 1997.

The Unconquered Knight; a Chronicle of the Deeds of Don Pero Niño, Count of Buelna, by His Standard-bearer Gutierre Diaz de Gamez (1431-1449). Translated and selected from El Vitorial by Joan Evans. London, G. Routledge \& Sons, Ltd., 1928.

\section{Traditional ROMANGES THAT DEAL WITH INGEST GOMMITTED OR AVOIDED}

Romances de Silvana, about a father who seeks carnal union with his daughter, but the mother strategically replaces her in bed to save the family from dishonor and sin

Romances de Delgadina, a daughter who resists, or in some versions succumbs, to the insistent pretensions of her father; the girl's mother and sisters may refuse to help her in her plight; Delgadina reproaches both parents before she dies

Romances de Tamar, raped by her brother; based on the biblical story in II Samuel, 13

Romances de don Bueso y la hermana cautiva, in which a knight falls in love with a captive Moorish girl only to discover that she is his lost sister, taken prisoner in an earlier raid; he restores her to the family Romancero. Ed. Paloma Díaz-Mas. Estudio preliminar de Samuel G. Armistead. Barcelona: Crítica, 1994.

Romancero. Ed. estudio y notas de Michelle Débax. Madrid: Alhambra, 1982.

See article by Sarah Portnoy on Delgadina in this issue, including a modern Cuban version of the Romance de don Bueso y la hermana cautiva. 


\section{Story of King of Hungary and his daughter}

Historia del rey de Hungria, Catalan romance novel, published by Bufarull in 1857.

Incest between father and daughter based on the French tale La manekine.

\section{See article by Emily Francomano in this issue.}

\section{APPENDix 2 \\ Teaching Sensitive Topics}

\section{Steps for introducing material in class and managing discussion}

Content Disclosure - Make an honest disclosure of where you're going with this topic and how you hope to approach it within context of the course and using whichever applicable methodologies.

In the interdisciplinary course on Incest in Medieval Literature, Culture and Law (four sections co-taught by three faculty members), we each gave some background of how our Program in Medieval E Renaissance Studies tries to explore interdisciplinary issues that fall between the cracks of the normal curriculum, especially in social history, with examples from other courses w've taught, such as Women and Mysticism, The Abandonment of Children, Inquisition, etc. Incest is a persistent theme in literature, religion and law, but in medieval times a subject that differed in many ways from modern concerns exclusively about psychological harmful sexual activity between those who are closely related, genetic consequences, and child abuse.

Distance from Topic - Explain how you want to keep this study and discussion at arm's length for everyone's comfort.

Medieval and Renaissance Studies can aluays use its primary sources to establish a temporal distance, for instance noting that the now almost total conflation of incest and child abuse in the popular imagination is barely a century old. Prior to about 1900, there is very little talk about the sexual abuse of children, and in the Middle Ages none at all. Incest legislation starts as an experiment in social engineering to help consecrate the sacramental quality of marriage in opposition to merely feudal, tribal or commercial alliances. But distance can also be established by sharpening any specific professional lens: economists might conduct research about prostitution as a black market commodity that only slowly moves from barter to a cash transaction without getting into a denunciation of the treatment of women in a patriarchal society. 
And historians of royal prerogatives might discuss incest prohibitions as a check on unbridled concentration of wealth and power in a self convergent clan.

Parameters of Content Issues \& Exclusionary Markers - Announce limits of what you'll cover and what you're not going to address and why or why not.

In the section on Incest in Medieval Literature, Culture and Law, each instructor gave opening statements about the different ways one could look at incest and which ones we're not exploring in this course: e.g., that there would not be any sort of comprehensive coverage of anthropological perspectives, feminist approaches, rape as violence, genetic counseling, what happens to the children of incestuous unions, etc. We stated that we would try to talk about incest as part of the medieval imaginary and discover what sort of symbolic value it had in terms of religious or dynastic performance, confirmation of power differential, common excuses/rationales offered for this sort of behavior when it did happen, communal consequences of individual transgressions, and the spiritual importance given to acts of incest including among those only related through baptismal sponsorship as godfathers and godmothers.

Consensus Breaks - Pause every now and then (and not just when things get heated, or it will look like sending the emotionally invested parties into a "time out") to ask "Okay, at this point everyone please take a moment to jot down and then share with the group any basic statement about this material on which we could all agree at this point in our study."

Instructor's attitude toward material - Share why you think this is a worthy research topic, how you started your specific inquiry, and what you think it can reveal within the confines of your professional discipline (literary or cultural studies, anthropology, religious studies, psychology, etc.).

Instructor's relative authority in this area - Admit what you know and how you've tried to systematize your research in this area; also what bibliography you've read to broaden your perspectives beyond the range of your disciplinary approach. If all of your background reading has been in canon law, the spiritual kinship of vowed religious, and medieval legislation concerning inheritance rights, it's okay to let everyone know that up front. 


\section{Who has different or complementary expertise and how to contact} them - Provide a short list of resource people who can help students explore this issue from different angles they may want to explore for their own research or out of personal curiosity.

Faculty teaching Incest in Medieval Literature, Culture and Lau prepared a script for the first day when we all made sure w'e said something like "A course on incest may start you thinking about incidents from our oum life or what you heard about the experiences of others. It's okay to want to talk to a clergy person or someone in the Counseling Center about specific incidents with yourself or others close to you and to ask 'Does that "count" as incesl?" We also gave a roster of faculty who has been part of the preceding faculty seminar and talked about their areas of expertise and research interests.

Deciding on Professional Guidance or a Safety Contract - Before teaching a course containing a prolonged consideration of sometimes truly disturbing material such as incest, torture, rape or suicide, the instructor might want to have a session or two with colleagues or trained campus clinicians who can talk about their professional experience and what students are likely to bring to these topics.

Asking students to sign a "safety contract" may help them take their responsibility to themselves and each other more seriously, and we let our own students know that -in the case of the course on Incest in Medieval Literature, Culture and Lau-even before we started to design the multi-section course, we met for a week-long Faculty Seminar to survey the anticipated target readings and coach each other on classroom possibilities and scenarios. In addition to the four participating medievalists, there was a physician from the Student Health Center: a deeply experienced clinical psychologist from the Counseling Center; and an anthropologist interested in transcultural expressions of the incest taboo. We had talked about using a safety contract for the Incest course, a sort of signed agreement that anyone who finds him-or herself troubled by the discussion, or by memories of incidents from their oun past or episodes that others have shared with them, promises to go to the Counseling Center to sort out their feelings. In the end. we decided that presenting a safety contract would be more likely to exacerbate the anxiety level instead of relieving it. 


\section{APPENDIX 3 REFERENGE Bibliography ON Incest in Classical and Medieval Studies}

Archibald, Elizabeth. Incest and the Medieval Imagination. Oxford: Clarendon Press, 2001.

Archard, David. Sexual Consent. Boulder: Westview Press, 1998.

Armistead, Samuel G. "Dos princesas castellanas en la tradición cidiana".

A: "La infanta Doña Urraca, enamorada del Cid": B: "La infanta

Doña Elvira, casada con el conde don García de Cabra". La tradición épica de las "Mocedades de Rodrigo»". Salamanca: Ediciones Universidad de Salamanca, 2000. 49-57. Revisions of: "The Enamored Doña Urraca' in Chronicles and Balladry". Romance Philology 11 (19571958): 26-29; and "An Unnoticed Epic Reference to Doña Elvira, Sister of Alfonso VI". Romance Philology 12 (1958-1959): 143-47.

Assis, Yom Tov. "Sexual behaviour in Mediaeval Hispano-Jewish

Society". Jewish History. Essays in Honour of Chimen Abramsky. Ed.

Ada Rapoport-Albert and Steven J. Zipperstein. London: Peter Halban, 1988, 25-59.

Barnes, Elizabeth, Ed. Incest and the Literary Imagination. Gainesville: UP of Florida, 2002.

Bellotti, Raymond A. Good Sex. Lawrence: U of Kansas Press, 1993.

Beltrán, Rafael. "La maldición a la mujer y a la ciudad en el romance cidiano 'En las almenas de Toro"'. Actes del VII Congrés de l'Associació Hispànica de Literatura Medieval. 3 vols. Eds. Santiago Fortuño Llorens, Tomàs Martínez Romero. Castelló: Universitat Jaume I, 1999. 1: 319-36.

Bergen, Raquel Kennedy. Issues in Intimate Violence. London: SAGE Publications, 1988.

Barnes, Elizabeth. Ed. Incest and the Literary Imagination. Gainesville:

U Press of Florida, 2002.

Black, Nancy. Medieval Narratives of Accused Queens. Gainesville: UP of Florida, 2003.

Bliss, Lee. "The Renaissance Griselda: A Woman For All Seasons". Viator 23 (1992): 301-43.

Blume, E. Sue. Secret Survivors: Uncovering Incest and Its Effects in Women. NY: Ballantine, 1985.

Boehrer, Bruce Thomas. Monarchy and Incest in Renaissance England. Philadelphia: U of Pennsylvania P, 1992. 
Brewster, Paul G. The Incest Theme in Folksong. FF Communications, 212. Helsinki: Academia Scientiarum Fennica, 1972.

Brownlee, Marina Scordilis. "Language and incest in Grisel y Mirabella". Romanic Review 79:1, 1988, 107-28.

Brundage, James A. Sex, Law and Christian Society in Medieval Europe. Chicago: U of Chicago P, 1987.

-. Sex, Lau, and marriage in the Middle Ages. Brookfield, VI: Variorum, 1993.

Bullón-Fernández, María. Fathers and Daughters in Gouer's Confessio Amantis. Cambridgc: D.S. Brewer, 2000.

Caldwell, Susan I Javens. "Lrraca of Zamora and San Isidoro in León: Fulfillment of a Legacy". Woman's Art Joumal 7.1 (1986): 19-25.

Candib, Lucy M. "Incest and Other Harms to Daughters Across Cultures. Maternal Complicity and Patriarchal Power". Women's Studies International Forum 22.2 (1999): 185-201.

Chalmeta, Pedro. "El matrimonio según el Kitab al-Wata’iq de Ibn alAttar (s. X)". Anaquel de estudios árabes 6 (1995): 29-70.

Chamas, Jacqueline. "I e clergé et l'incest spirituel dans trois romans du XVIII ' sic̀cle: Le Portier des Chartreux, Thérèse philosophe et Margot la ravandeuse". Fighteenth-Century Fiction, special issue on Fiction $\dot{\sigma}^{\circ}$ Religion / Genre Romanesque et Religion 15.3-4 (April-July 2003): $687-704$.

Champagne, Rosario. "The Law of the (Nameless) Father: Mary Shelley's Mathilde Mathilda and the Incest Taboo". Forming and Reforming Identity: Eds. Carol Siegel and Ann Kibbey. New York: New York UP, 1995. 257-84.

Chicote, Gloria Beatriz. "Fl romancero panhispánico: reelaboración del tema del incesto en la tradición argentina". Hispanófila 122 (1998): $41-54$.

Glark, Robin E. The Encyclopedia of Child Abuse. NY: Facts on File, 1989. Córdoba de la Llave, R. El instinto diabólico. Agresiones sexuales en la Castilla medieval. Córdoba: U de Córdoba, 1994.

Crawford, Katherine. European Sexualities, 1400-1800. Cambridge, England: Cambridge UP, 2007.

de Jong, Maykc. "To the Limits of Kinship: Anti-Incest Legislation in the Early Medicval West (500-900)". From Sappho to De Sade: Moments in the History of Sexuality. Fd. Jan Bremmer. London \& New York, 1989. $36-59$.

Deyermond, Alan. "Motivos folclórcos y técnica estructural en el Libro de Apolonio". Filología 13 (1968-1969): 121-49. 
—_. "La sexualidad en la épica medieval española". Nueva revista de filología hispánica 36 (1988): 767-86.

De Young, Mary. "Women as Mothers and Wives in Paternally Incestuous Families. Coping with Role Conflict". Child Abuse and Neglect 18 (1994): 73-83.

Dillard, Heath. Daughters of the Reconquest. Women in Castilian Toun Society, 1150-1300. Cambridge: Cambridge UP, 1988.

Doane, Janice and Devon L. Hodges. Telling Incest. Narratives of Dangerous Remembering from Stein to Sapphire. Ann Arbor: U of Michigan P, 2001.

Dominelli, Lena. "Father-Daughter Incest: Patriarchy's Shameful Secret". Critical Social Policy 66 (1986): 18-22.

Donavin, Georgiana. "Taboo and Transgression in Gower's "Apollonius of Tyre". Domestic Violence in Medieval Texts. Ed. Eve Salisbury, Georgiana Donavin, and Merrall Llewelyn Price. Gainesville: U Press of Florida, 2002. 94-121.

Donnelly, Colleen. "Silence or Shame: How Women's Speech Contributes to Generic Conventionality and Generic Complexity in The Canterbury Tales". Language and Style 24.4 (1991): 433-43.

Dubinky, Karen. Improper Advances. Chicago: U of Chicago P, 1993.

Duby, Georges. Love and Marriage in the Middle Ages. [Mâle Moyen Age: de l'amour et autres essais. Paris: Flammarion, 1967]. Trans. Jane Dunnet. Chicago: U of Chicago P, 1996.

Dundes, Alan. "The Psycholanalytic Study of the Grimms' Tales: "The Maiden Without Hands" (AT 706)". Folklore Matters. Knoxville: U of Tennessee P, 1989. 112-50.

Edmunds, Lowell. Oedipus. The ancient legend and its later analogues. Baltimore: Johns Hopkins UP, 1985.

Egan, Linda. "Patriarcado de mi vida, tus castigos estoy sufriendo: El fondo histórico-psícquico del romance-corrido Delgadina". Bulletin of Hispanic Studies 73 (1996): 361-76.

Eming, Jutta. "Questions on the theme of incest in courtly literature". The Court Reconvenes: Courtly Literature Across the Disciplines. Selected Papers from the Ninth Triennial Congress of the International Courtly Literature Society, University of British Columbia, 25-31 July 1998. Eds. Barbara K. Altman, Carleton W. Carroll. Woodbridge, Suffolk: Boydell \& Brewer, 2003. 153-60.

Fantham, Elaine. "Nihil iam iura naturae valent': incest and fratricide in Seneca's Phoenissae". Ramus. Critical Studies in Greek and Roman Literature. (Berwick) 12, Fasc. 1 (1983): 61-76. 
Fenster, Thelma. "Beaumanoir La Manekine: Kin, D(r)ead, Incest, Doubling, and Death". American Imago 39.1 (1982): 41-58.

Francomano, Emily C. "The Hands of Philippe de Remi's Manekine". Mediterranean Studies 15 (2006): 1-20.

_- "Manuscript Matrix and Meaning in Castilian and Catalan Anthologies of Saints' Lives and Pious Romance". Bulletin of Hispanic Studies 81:2 (2004): 139-53.

Froula, Christine. "The Daughter's Scduction: Sexual Violence and Literary History". Daughters and Fathers. Ed. Lynda E. Boose and Betty S. Flowers. Baltimore: Johns Hopkins UP, 1989. 111-35.

García Herrero, María del Carmen. Las mujeres en Zaragoza en el siglo XV. 2 vols. Zaragoza: Ayuntamiento, 1990.

Gelting, Michael H. "Marriage, peace and the canonical incest prohibitions: making sense of an absurdity?" Nordic Perspectives on Medieval Canon Lau. Ed. Mia Korpiola (Publications of Matthias Calonius Society, 2). Saarijärvi: Gummerus Kirjapiano Oy, 1999. 93-124.

Godden, Malcolm R. The trouble with Sodom. Literary responses to biblical sexuality". Bulletin of the John Rylands University Library of Manchester 77:3 (1995): 97-119.

Goepp, Philip H. "The Narrative Material of Apollonius of Tyre". English Literary History 5 (1938): 150-72.

Goldberg, Harriet. Motif-index of Folk Narratives in the Pan-Hispanic Romancero. Medieval \& Renaissance lexts and Studies, 206. Tempe, AZ: Arizona Center for Medieval and Renaissance Studies, 2000.

- Motif-Index of Folk Narratives in the Pan-Hispanic Romancero. Medieval \& Renaissance Texts and Studies, 206. Tempe, AZ: Arizona Center for Medieval and Renaissance Studies, 2000.

- - "Sexual Humor in Misogynist Medieval Exempla". Women in Hispanic Literature: Icons and Fallen Idols. Ed. Beth Miller. Berkeley, Los Angeles and London, 1983. 67-83.

Gonis, N. "Incestuous Twins in the City of Arsinoe". Zeitschrift fur Papyrologie und Epigraphik 133 (2000): 197-98.

Goody, Jack. The Development of the Family and Marriage in Europe. Past and Present Publications. New York: Cambridge UP, 1983.

- - Kinship and marriage in medieval Hispanic chivalric romance. Turnhout, Belgium: Brepols, 2001.

Grauerholz, Elizabeth; Mary Koralewski. Sexual Coercion: a sourcebook on its nature, causes, and prevention. Lexington, Mass.: Lexington Books, 1958. 
Gravdal, Kathryn. "Confessing Incests: Legal Erasures and Literary Celebrations in Medieval France". Comparative Literature Studies 32.2 (1995): 280-96.

Green, C.M.C. "Claudius, Kingship, and Incest". Latomus. Revue d'études latines. (Bruxelles) 57.4 (1998): 765-91.

Guarino, Augusto. "Contra natura? Motivi dell'incesto in alcuni autori del Cinquecento spagnolo". Scrittori contro" modelli in discussione nelle letterature iberiche. Atti del Convegno di Roma dell'Associazione Ispanisti Italiani, 15-16 marzo 1995. Roma: Bulzoni Editore, 1996. 53-63.

__ . "Sibling Symmetry and the Incest Taboo in Tirso's Habladme en entrando". Tirso de Molina: His Originality Then and Now. Eds. Henry W. Sullivan and Raúl Galoppe. Ottawa: Ottawa Hispanic Studies. 1996. 162-86.

—_. "From Bandello to Freud and Lacan: Lope de Vega's El Castigo sin Venganza". Oral Tradition and Hispanic Literature. Essays in honor of Samuel G. Armistead. Edited by Michael M. Caspi. New York: Garland Publishing. 1995. 583-602.

Gutiérrez Estévez, Manuel. "El incesto en el romancero popular hispánico. Un ensayo de análisis estructural”. Madrid: Universidad Complutense. 1981. DOGTORAL THESIS

Haboucha, Reginetta. "Clerics, their wives, and their concubines in the Partidas of Alfonso el Sabio". Homo Camalis. The Carnal Aspect of Medieval IIuman Life. Ed. Helen Rodite Lemay (Acta, 14). Binghamton: Center for Medieval and Early Renaissance Studies, State University of New York at Binghamton, 1990. 85-104.

Harney, Michael. Kinship and polity in the "Poema de mío Cid». West Lafayette: Purdue UP, 1993.

- - Kinship and marriage in medieval Hispanic chivalric romance. Turnhout, Belgium: Brepols, 2001.

Haro, Marta. "De las buenas mujeres: su imagen y caracterización en la literatura ejemplar de la Edad Media". Medioevo y Literatura: Actas del V Congreso de la Asociación Hispánica de Literatura Medieval (Granada, 27 septiembre - 1 octubre 1993). 4 vols. Ed. Juan Paredes. Granada, 1995. 2: 457-76.

Harrison, S.J. "Mythological incest: Catullus 88". Classical Quarterly 46.2 (1996): 581-82.

Harvey, Carol J. "Incest, identity and uncourtly conduct in La Manekine". The Court Reconvenes: Courtly Literature Across the Disciplines. Selected Papers from the Ninth Triennial Congress of the International Courtly Literature Society, University of British Columbia, 25-31 July 1998. Eds. 
Barbara K. Altman, Carleton W. Carroll. Woodbridge, Suffolk: Boydell \& Brewer, 2003. 161-68.

Hay, Beatriz Mariscal. "Incest and the Traditional Ballad". Acta Ethnographica Hungarica 47.1-2 (2002): 19-27.

Herman, J. L. and L. Hirschman. Father-Daughter Incest. Cambridge MA: Harvard LP, 1981.

Herzfeld, Michael. "Silence, Submission, and Subversion: Toward a

Poetics of Womanhood". Contested identities: Gender and Kinship in

Modern Greece. Eds. Peter Loizos and Evtymios Papataxiardos.

Princeton: Princeton LP, 1991.

Hernández, Francisco J. "Sobre los origenes del español escrito". Voz y Letra X/2 (1999) 133-66: 154-57.

Hernández Franco, Juan Peñafiel Ramón, Antonio. "Parentesco, linaje y mayorazgo en una ciudad mediterránea: Murcia (siglos XVXVIII)". Hispania: Revista española de historia 58:1 (1998): 157-83. Herlihy, David. Women, Family and Society in Medieval Europe: Historical Essays. Providence: Berghahn Books, 1995.

Medieval Households. Cambridge: Harvard LP, 1985.

"Making Sense of Incest: Women and the Marriage Rules of the Early Middle Ages". Lau', Custom, and the Social Fabric in Medieval Europe. Essays in Honor of Bryce Lyon. Eds. Bernard Bachrach and David Nicholas. Kalamazoo, MI, 1990. 1-16

Holt, Philip "Sex, Tyranny, and Hippias' Incest Dream (Herodotos 6.107)". Greek, Roman and Byzantine Studies 39.3 (1998) 221-42.

Jeay, Madeleine. "Chercher une fille, une épouse. Sexualités déviantes et parcours de rédemption". Florilegium 18:1 (2002 [for 2001]): $65-82$.

Kamps, Ivo. "Magic, women, and incest: the real challenges in Sir Gauain and the Green Knight". Exemplaria: A Journal of Theory in Medieval and Renaissance Studies 1.2 (1989): 313-36.

Krappe, Alexander Haggarty. "La Belle Hélène de Constantinople". Romania 63 (1937): 324-53.

Krow-Lucal, Martha. "The Jezebel Paradigm: Construction of an Image for doña Urraca". Oral Tradition and Hispanic Literature: Essays in Honor of Samuel G. Armistead. Ed. Michacl Caspi and John Miles Foley. New York: Garland, 1995. 353-83.

Lambert, Jacques-Numa. "L'inceste souhaité ou prohibé comme réalisant l'androgynie prêtée aux dieux (1 ${ }^{\text {cre }}$ partie)". Kernos 6 (1993): 139-205.

__. "Linceste souhaite ou prohibe comme realisant l'androgynie pretee aux dieux (2 ${ }^{\text {emc }}$ partie)". Kernos 7 (1994): 231-71. 
Laskaya, Anne. "The Rhetoric of Incest in the Middle English Émaré". Violence Against Women in Medieval Texts. Ed. Anna Roberts. Gainesville: U of Florida P, 1998.

Lindahl, Carl, John McNamara, and John Lindow, eds. Medieval Folklore: An Encyclopedia of Myths, Legends, Tales, Beliefs, and Customs. Santa Barbara: ABC-CLIO, 2000. [republished as Medieval folklore: a guide to myths, legends, tales, beliefs, and customs. Oxford, New York: Oxford UP, 2002].

Lozano-Renieblas, Isabel. Novelas de aventuras medievales: género y traducción en la Edad Media hispánica. Kassel: Edition Reichenberger, 2003.

_. Novelas de aventuras medievales: género y traducción en la Edad Media hispánica. Kassel, Germany: Edition Reichenberger , 2003.

McLaughlin, Megan. “Abominable Mingling': Father-Daughter Incest and the Law". Medieval Feminist Newsletter 24 (1997): 26-30.

Martin, Therese. "The Art of a Reigning Queen as Dynastic Propaganda in Twelfth-Century Spain". Speculum 80.4 (2005): 1134-71.

Martínez González, Esther. "Matrimonio y divorcio islámicos". Proyección histórica de España en sus tres culturas: Castilla y León, América y el Mediterráneo. Ed. Eufemio Lorenzo Sanz. 3 vols. Valladolid: Junta de Castilla y León, Consejería de Cultura y Turismo, 1993. 3: 12530 .

Mattoso, José. "Pecados secretos". Kunigunde-consors regni. Eds. Stefanie Dick, Jörg Jarnut, und Matthias Wemhoff. Mittelalterstudien des Instituts zur Interdisziplinären Erforschung des Mittelalters und seines Nachwirkens, Paderborn, 5. München: Wilhelm Fink, 2004. $11-42$.

Menéndez Pidal, Ramón and E. Levi Provençal . "Alfonso VI y Su Hermana la Infanta Urraca". Al Andalus 13 (1948): 157-66.

Miller, Alice. Thou shalt not be aware: Society's Betrayal of the Child. New American Library, Collins Publishers, 1984.

Mirrer, Louise. Women, Jews $\mathcal{E}^{\circ}$ Muslims in the Texts of Reconquest Castile. Ann Arbor: U of Michigan P, 1996.

—. "Entre la gente se dice: Gossip and Indirection as Modes of Representation in the Romances noticieros". Studies on Medieval Spanish Literature in Honor of Charles F. Fraker. Ed. Mercedes Vaquero and Alan Deyermond. Madison: Hispanic Seminary of Medieval Studies, 1995. 219-27.

Moral, Celia de. Árabes, judías y cristianas: mujeres en la Europa medieval. Granada: U de Granada, 1993. 
Newman, Barbara. "Intimate Pieties: Holy Trinity and Holy Family in the Late Middle Ages". Religion and Literature 3.1 (1999): 77-101. Nowlin, Steele. "Narratives of incest and incestuous narrative: memory, process and the Confessio Amantis's "Middel Weie". Journal of Medieval and Early Modern Studies 35.2 (2005): 217-44.

Parrilla, Carmen. "Casta de desafío". Atalaya: Revue française d'études médiévales lispaniques 3 (1992): 155-63.

___. "El casamiento como transgresión del orden: un ejemplo en la literatura medieval". Atalaya: Revue française d'études médiérales hispaniques 6 (1995): 41-47.

Payer, Pierre $J$.

Payer, Pierre J. "Sex and Confession in the Thirteenth Century". Sex in the Middle Ages: A Book of Essays. Ed. Joyce E. Salisbury. New York and London: Garland, 1991. 126-42.

- The Bridling of Desire: Vieu's of Sex in the Later Middle Ages. Toronto: $\mathrm{L}$ of Toronto P, 1993.

Pedrosa, José Manuel. "Por qué vuelan de noche las lechuzas, por murió joven Roldán, por qué se llama una novela Cien años de soledad: exclusión, soledad y muerte en los relatos de incesto". "Entra mayo y sale abril": Medieval Spanish Lilerary and Folklore Studies in Memory of Harriet Goldberg. Eds. Manuel Da Costa Fontes, Joseph T. Snow. Newark, Delaware: Juan de la Cuesta Press, 2005. 259-79.

Phipps, Carolyn C. "El incesto, las adivinanzas y la música: diseños de la geminación en el Libro de Apolonio". El Crotalón (Madrid) 1 (1984): $807-18$.

Pollak, Ellen. Incest and the English Novel, 1680-1814. Baltimore: Johns Hopkins LP, 2003.

Prat Ferrer, Juan José. "El mito de Edipo en la tradición culta occidental y sus interpretacioncs". Revista de Folklore 303 (2006): 75-88.

Ratcliffe, Marjorie. "Urraca: De heroína épica a heroína romántica". Medioevo y literatura. Ed. Juan Paredes. Granada: Universidad de Granada, 1995. 113 -22.

Rank, Otto. The Incest Theme in Literature and Legend: Fundamentals of a Psychology of Literary Creation. [Das Inzest-Motiv in Dichtung und Sage: Grundzüge einer Psychologie des dichterischen Schaffens. Leipzig-Wien: Franz Deuticke, 1912|. Trans. Gregory C. Richter. Baltimore: Johns Hopkins LP, 1992.

. The Myth and Birth of the Hero. A Psychological Exploration of Myth. [Der Mythus von der Geburt des Helden: Versuch einer psychologischen Mythendeutung. Leipzig: Deuticke, 1909]. New York: Vintage Books, 1964. 
Régnier-Bohler, Danielle. "L'inceste et les voies de la pénitence: l'histoire d'une fondation chez Jehan de Saint Quentin". Femmes. Mariages - Lignages, XII ${ }^{e}$-XIV $V^{e}$ siècles. Melanges offert à Georges Duby. Ed. Jean Dufournet, et al. Bruxelles: De Boeck-Wesmael, 1992. 289-303.

Ricapito, Joseph V. "From Bandello to Freud and Lacan: Lope de Vega's El Castigo sin Venganza". Oral Tradition and Hispanic Literature: Essays in Honor of Samuel G. Armistead. Ed. Michael M. Caspi. Albert Bates Lord Studies in Oral Tradition, 15. New York: Garland, 1995. 583-602.

Rodríguez Ortiz, Victoria. Historia de la violación, su regulación jurídica hasta fines de la Edad Media Madrid: Comunidad de Madrid, 1997. Rosa, María de Lurdes. "Marriage et empêchements canoniques de parenté dans la société portugaise (1455-1520)". Mélanges de l'École française de Rome. Moyen Âge. 108:2 (1996): 525-608.

Roussel, Claude. "Aspects du père incestueux dans la littérature médiévale". Amour, Marriage et transgressions au moyen âge: actes du colloque des 24, 25, 26 et 27 mars 1983, Université de Picardie, Centre d'études médiévales; Ed. Danielle Buschinger and André Crépin. Göppingen: Kümmerle, 1984. 47-62.

Rubin, Gayle. "The Traffic in Women: Notes on the 'Political Economy' of Sex". Toward an Anthropology of Women. Ed. Rayna R. Reiter. New York: Monthly Review Press, 1975. 157-210.

Rubio Vela, Agustín. "Crimen de incesto en Alcublas (1489)". Saitabi: Revista de historia, arte y arqueología. Volum Extraordinari, 1996. 65-84.

Rubio García, Luis. "Dos contratos matrimoniales". Homenaje al professor Juan Torres Fontes. 2 vols. Murcia: Universidad de Murcia, Academia Alfonso X el Sabio, 1987. 2: 1493-97.

Sabbah, G. "Castum, incestum: elements d'une ethique sexuelle dans l'Histoire d'Ammien Marcellin”. Latomus 53.2 (1994): 317.

Savage, Anne. "Clothing Paternal Incest in The Clerk's Tale, Émare, and the Life of St. Dympna". Medieval Women: Texts and Contexts in Late Medieval Britain. Ed. Jocelyn Wogan-Browne, et al. Turnhout: Brepols, 2001. 345-61.

Scheidel, Walter. "Incest Revisited: Three Notes on the Demography of Sibling Marriage in Roman Egypt". Bulletin of the American Society of Papyrologists 32.3-4 (1995): 143-55.

Schulenberg, Jane Tibbets. Forgetful of Their Sex: Female Sanctity and Society, ca. 500-1100. Chicago: U of Chicago P, 1998. 
Shell, Marc. "The Want of Incest in the Human Family, Or, Kin and Kind in Christian Thought". Journal of the American Academy of Religion 52 (1994): 625-50.

Smith, Charles Edward. Papal Enforcement of Some Medieval Marriage Lau's. Baton Rouge: Louisiana State University Press, 1940.

Smith, Dawn. "Crossing Generic Boundaries: the Lse of the Rape of Tamar". Journal of IIspanic Literature 10 \& 11 (1997): 37-45.

Smith, Wendell. "Marital canon-law dilemmas in the Libro del caballero Zifar". La corónica 27:3 (1999): 187-206.

Soble, Alan, Ed. The Philosophy of Sex: Contemporary Readings. Lanham: Powman \& Littlefield, 2002.

Sprengnether, Madelon. "Undoing Incest: A Meditation on Daughters and Fathers". Modern Philology 89.4 (1992): 519-36.

Stone, Marilyn. Marriage and Friendship in Medieval Spain. NY: Peter Lang, 1990.

Taggart, James M. Enchanted Maidens: Gender Relations in Spanish Folktales of Courlship and Marriage. Princeton: Princeton UP, 1990. Tapia, María Cruz Muriel. Antifeminismo y subestimación de la mujer en la literatura medieval castellana. Cáceres: Editorial Gaudiloba, 1991.

Taylor, Archer. "Riddles Dealing with Family Relationships". The Joumal of American Folklore 51. 199 (1938): 25-37.

Thorne, W.B. "Pericles and the Incest-Fertility Opposition". Shakespeare Quarterly 22 (1971): 43-56.

To Figueras, Lluís. Familia i Hereu a la Catalunya Nord-Oriental (Segles $X-X I I)$. Próleg de Pierre Bonnassie. Barcelona: Publications de l'Abadia de Montserrat, 1997.

Urbina, Eduardo. "Incesto en El celoso extremeño de Cervantes y en LÉcole. des femmes de Molière". Homenaje a Antonio Vilanova. Barcelona: Universidad, 1989. 709-21.

Vernant, Jean-Pierre. "From Oedipus to Periander: Lameness, Tyranny, Incest in I egend and History". Oxford Readings in Greek Religion. Ed. Richard Buxton, Oxford: Oxford UP, 2000. 109-29.

Vigarello, Georges. A History of Rape: Sexual Violence in France from the $16^{\text {th }}$ to the $20^{\text {th }}$ century. [Histoire du viol: XVI-XX siècle. Paris : Seuil, 1998]. Cambridge: Polity Pres, 2001.

Walecka Anna. "Incest and Death as Indices of the Female Hero in Romance”. Romance Languages Annual. 4 (1992): 159-65.

_. . "The Concept of Incest: Medieval French and Normative Writings in Latin". Romance Languages Annual 5 (1993): 117-23. 
White, Tristán Harvey E. "The Taboo of Antioch: Incest and its Consequences in the Libro de Apolonio". 'Quien hubiese tal ventura': Medieval Hispanic Studies in Honour of Alan Deyermond. Ed. Andrew M. Beresford. London: Dept. of Hispanic Studies, Queen Mary and Westfield College, 1997. 57-6

Wood, Ian. "Incest, law and the Bible in sixth-century Gaul". Early Medieval Europe 7:3 (1998): 291-303. 